\title{
Offshore wind speed and wind power characteristics for ten locations in Aegean and Ionian Seas
}

\author{
Haralambos S Bagiorgas ${ }^{1, *}$, Giouli Mihalakakou ${ }^{1}$, \\ Shafiqur Rehman ${ }^{2,3}$ and Luai M Al-Hadhrami ${ }^{2}$ \\ ${ }^{1}$ Department of Environmental and Natural Resources Management, University of Ioannina, Seferi 2 , \\ 30100 Agrinio, Greece. \\ ${ }^{2}$ Center for Engineering Research, Research Institute, King Fahd University of Petroleum and Minerals, \\ Dhahran 31261, Saudi Arabia. \\ ${ }^{3}$ Mechanical and Aeronautical Engineering Department, University of Pretoria, Pretoria, South Africa. \\ ${ }^{*}$ Corresponding author.e-mail: chbagior@cc.uoi.gr
}

This paper utilizes wind speed data measured at 3 and $10 \mathrm{~m}$ above water surface level using buoys at 10 stations in Ionian and Aegean Seas to understand the behaviour of wind and thereafter energy yield at these stations using $5 \mathrm{MW}$ rated power offshore wind turbine. With wind power densities of 971 and $693 \mathrm{~W} / \mathrm{m}^{2}$ at $50 \mathrm{~m}$ above water surface level, Mykonos and Lesvos were found to be superb and outstanding windy sites with wind class of 7 and 6 , respectively. Other locations like Athos, Santorini and Skyros with wind power density of more than $530 \mathrm{~W} / \mathrm{m}^{2}$ and wind class of 5 were found to be the excellent sites. Around 15-16\% higher winds were observed at $10 \mathrm{~m}$ compared to that at $3 \mathrm{~m}$. Lower values of wind speed were found during summer months and higher during winter time in most of the cases reported in the present work. Slightly decreasing ( $\sim 2 \%$ per year) linear trends were observed in annual mean wind speed at Lesvos and Santorini. These trends need to be verified with more data from buoys or from nearby onshore meteorological stations. At Athos and Mykonos, increasing linear trends were estimated. At all the stations the chosen wind turbine could produce energy for more than $70 \%$ of the time. The wind speed distribution was found to be well represented by Weibull parameters obtained using Maximum likelihood method compared to WAsP and Method of Moments.

\section{Introduction}

The power of the wind in good onshore locations has already been transformed to an opportunity for economic profit and is becoming competitive with other power generation methods. The main advantage of offshore wind power is that wind speeds are generally higher than over land (Bailey et al. 2002). The other factor, which encourages offshore wind farm development, is the reduced wind turbulence. Thus, the offshore turbines are likely to have less fatigue stresses. Musial and Butterfield (2004) reported the cost of offshore wind energy to be $\$$ US0.051/kWh based on a generic $5 \mathrm{MW}$ rated capacity wind machine for a hypothetical wind farm of $500 \mathrm{MW}$ installed capacity. The global cumulative offshore wind power installed capacity reached $2940 \mathrm{MW}$ with an addition of $883 \mathrm{MW}$ in 2010 alone, a value almost $52 \%$ more than that installed in 2009. According to EWEA 2010 statistics, annual additions in offshore global wind power installed capacity present an increasing trend for

Keywords. Offshore wind power assessment; Ionian Sea; Aegean Sea; buoys; wind speed; Weibull distribution; frequency distribution. 
almost each year from 2001 to 2010, making the cumulative wind power installed capacity growing rapidly (EWEA 2010).

Back in 1994, Gaudiosi (1994) presented a general overview of the offshore wind energy activity for the Mediterranean and other European Seas. Emphasis was given to resource assessment, planning, technical development, applications, economics, and environment. Still (2001) presented the details of the first offshore wind farm to be built in United Kingdom back in 2001. This wind farm was planned to use wind turbines from Vestas. Manwell et al. (2002) presented a summary of the ongoing work on the assessment of the wind energy resource off the coast of southern New England in the United States. Their work consisted of a review of existing offshore wind data, the measurement of new data at an offshore site, correlation and prediction of long-term data at a new offshore site by reference to a longer-term island site and assessment of the overall coastal resource through the use of the MesoMap software. Rogers et al. (2003) and Manwell et al. (2007) presented an overview of the national and regional efforts to define the potential offshore wind energy resource in the United States.

According to NREL (Musial and Ram 2010), the United States leads the world in installed, landbased wind energy capacity, yet has no offshore wind generating capacity to date. Although the United States has built no offshore wind projects so far, about 20 projects representing more than 2000 MW of capacity are in the planning and permitting process. At the state level, only Texas has a leasing system for offshore wind. According to Zhixin et al. (2009), the potential of offshore wind energy is vast and the key techniques of offshore wind farm includes optimization and estimation, electric transmission and connection, system and stability operation, manufacturing excursion system investigation, and the base of wind generator, three connection projects based on light HVDC generator disperse control. Esteban et al. (2011) presented a brief revision of the state-of-the-art of offshore wind power, followed by a critical discussion about the causes of the recent growth that is currently taking shape. The discussion was based on the comparison of offshore wind energy with other renewable energies (like onshore wind, marine hydrodynamics, hydraulic, solar, etc.) and even with conventional power. According to Bilgili et al. (2011) offshore winds tend to flow at higher speeds than onshore winds, thus it allows turbines to produce more electricity. Estimates predict a huge increase in wind energy development over the next 20 years. Much of this development will be offshore wind energy.

Dhanju et al. (2008) provided the offshore wind resources assessment of the US state of Delaware.
They found year-round average wind power output of over $5200 \mathrm{MW}$, or about four times the average electrical consumption of the state. According to the authors, on local wholesale electricity markets, this could produce over $\$ 2$ billion/year in revenue. Pimenta et al. (2008) used meteorological station, satellite data (QuikSCAT), and both theoretical and practical measures of wind turbine performance to evaluate offshore wind power potential of southern coast of Brazil. Next, they used bathymetry and the properties of current wind-electric technology to develop maps of wind speed, wind power density, and practical turbine output in power units (MW). Pimenta et al. (2008) found the most favourable conditions along the coast between $281^{\circ} \mathrm{S}$ and $331^{\circ} \mathrm{S}$ in the shallower waters of south Brazil. Finally, they estimated a total resource of $102 \mathrm{GW}$ average electrical production in one coastal area equivalent to the electric demand of the entire country.

Dvorak et al. (2010) combined multi-year mesoscale modelling results, validated using offshore buoys with high resolution bathymetry to create a wind energy resource assessment for offshore California. Initial estimates showed that 1.4-2.3 GW, 4.4-8.3 GW, and 52.8-64.9 GW of deliverable power could be harnessed from offshore California using monopile, multi-leg, and floating turbine foundations, respectively. A single proposed wind farm near Cape Mendocino could deliver an average 800 MW of gross renewable power and reduce California's current carbon emitting electricity generation $4 \%$ on an energy basis (Dvorak et al. 2010). The electric power generation of co-located offshore wind turbines and wave energy converters along the California coast was investigated by Stoutenburg et al. (2010). They used meteorological wind data from the National Buoy Data Center to estimate the hourly power output from offshore wind turbine at the sites of the buoys. The authors estimated the offshore wind farm capacity factors from $30 \%$ to $50 \%$. Martin Mederos et al. (2011) used wind speed and direction data from 40 weather stations and satellite to develop the offshore wind resources atlas. The offshore atlas for Canary Island presented in Martin Mederos et al. (2011) was based on three combined models. The authors have drawn up three maps namely, one for mean wind speed, one for mean wind direction and one for dominant wind direction. The study concluded that a great offshore wind power potential exists in the islands.

During the last years a lot of discussion has been made concerning the renewable sourced energy potential that could be captured in the area of Eastern Mediterranean and especially in the islands of Aegean and Ionian seas. Various research works and tasks had been demonstrated 
trying to determine the maximum wind sourced energy potential in the area (Poulos et al. 1997; Incecik and Erdogmus 1995; Klaić et al. 2009; Borhan 1998; Hamad et al. 2006). Karamanis et al. (2011) assessed the offshore wind power potential of two sites, Zakynthos and Pylos in the Ionian sea by using two years mean wind speed at $10 \mathrm{~m}$. They found the annual mean wind speed at these two sites as 5.7 and $5.8 \mathrm{~m} / \mathrm{s}$, respectively. Offshore wind capacity factors of up to $48 \%$ for energy production were calculated with the existing offshore turbines technology at a hub height of $100 \mathrm{~m}$. The present study utilizes wind speed and direction data from 10 buoy stations in Ionian and Aegean seas to assess the offshore wind power potential in these areas.

The present paper has, as main objective, to thoroughly examine the wind characteristics for many offshore locations in the areas of Aegean and Ionian seas, as being areas with large differences in wind characteristics, even more between two neighbouring sites, by using the studied Weibull parameters of the areas. In addition, this study attempts to understand the behaviour of wind and thereafter energy yield at these stations using a $5 \mathrm{MW}$ rated power offshore wind turbine.

\section{Site and data description}

The study utilizes measured wind speed and wind direction data at 3-hr intervals from 10 buoy stations namely Athos, E1M3A, Lesvos, Mykonos, Petrokaravo, Santorini, and Skyros in Aegean Sea and Kalamata, Pylos, and Zakynthos in Ionian Sea. The data collection period varied between 3.1 and 11 years as can be seen from 6th column of the table 1 below. The latitude, longitude, the data collection periods are summarized in table 1 and the physical locations are depicted in figure 1 .

Two types of surface buoys are used in the selected sites: Oceanor Wavescan at Athos, E1M3A and Pylos (figure 1, locations 1, 2, 7) and Oceanor SeaWatch at Kalamata, Lesvos, Mykonos, Petrokaravo, Santorini, Zakynthos and Skyros (figure 1, locations: $3,4,5,6,8,9,10$ ). Wavescan buoy ${ }^{1}$ is a metocean data collection buoy that provides wave height, wave direction and meteorological parameters, sea surface temperature, salinity and temperature profiles. It is the ideal buoy for deep-water measurements, remote locations and strong current conditions. The buoy can also be fitted with numerous other sensors, to satisfy the scientist's specific configuration needs, such as oxygen, hydrocarbon, gamma radiation measurement and an optical sensor for algae detection. Seawatch buoy ${ }^{2}$ is a multi-sensor wave directional data buoy capable of measuring wave height and direction, ocean current speed and direction, meteorological parameters, sea surface temperature, salinity and temperature and salinity profiles. As a vertically stabilised buoy with low pitch/roll motion, it is ideally suited for wave, current and wind measurements in shallow water depth up to $500 \mathrm{~m}$. For water quality measurement, the buoy can be fitted with numerous other sensors, satisfying the customer's specific configuration needs, such as oxygen, hydrocarbon, gamma radiation measurement and an optical sensor for algae detection.

The data collection buoys used at the aforementioned sites are shown in figure 2. These buoys were instrumented to measure the air-pressure, air-temperature, wind speed and direction, wave height, period and direction, sea surface salinity and temperature, surface current speed and direction. The anemometer used in both types of buoys is the Young 04106 (four-blade propeller anemometer).

The Aegean Sea, an arm of the Mediterranean Sea, is located between the Greek peninsula on the west and Asia Minor on the east, while the island of Crete can be taken as marking its boundary on the south. The Aegean is connected through the straits of the Dardanelles, the Sea of Marmara, and the Bosporus to the Black Sea. It contains more than 3000 islands, with Crete as its largest island and is considered as the home of the earliest European civilization. The Aegean Sea covers about $214,000 \mathrm{~km}^{2}$ in area, and measures about $610 \mathrm{~km}$ longitudinally and $300 \mathrm{~km}$ latitudinally. The sea's maximum depth is $3543 \mathrm{~m}$ east of Crete. It also has a good connection to the Ionian Sea to the west, mainly, through the strait lying between the Peloponnese peninsula of Greece and Crete. The rocks making up the floor of the Aegean are mainly limestone, though often greatly altered by volcanic activity that has convulsed the region in relatively recent geologic times.

The Ionian Sea is also an arm of the Mediterranean Sea, south of the Adriatic Sea. It is bounded by southern Italy, including Calabria, Sicily and the Salento peninsula to the west, and by southwestern Albania and Greek peninsula to the east, containing a large number of Greek islands. It is connected with the Adriatic Sea to the north by the Strait of Taranto. The sea is one of the most seismic areas in the world.

North winds prevail in the Aegean Sea, although from the end of September to the end of May, 
Table 1. Summary of site specific coordinates and wind power class.

\begin{tabular}{|c|c|c|c|c|c|c|c|c|c|}
\hline Lactation & $\begin{array}{l}\text { Latitude } \\
\qquad(\mathrm{N})\end{array}$ & $\begin{array}{l}\text { Longitude } \\
\text { (E) }\end{array}$ & $\begin{array}{l}\text { Depth } \\
(\mathrm{m})\end{array}$ & $\begin{array}{l}\mathrm{DFL} \\
(\mathrm{km})\end{array}$ & Start date & End date & $\begin{array}{l}\text { Period } \\
\text { (years) }\end{array}$ & $\begin{array}{c}\text { WPD } \\
\left(\mathrm{W} / \mathrm{m}^{2}\right)\end{array}$ & $\begin{array}{l}\text { Wind } \\
\text { class }\end{array}$ \\
\hline Athos & $39^{\circ} 57^{\prime} 843^{\prime \prime}$ & $24^{\circ} 43^{\prime} 208^{\prime \prime}$ & 212 & 27.46 & $05 / 25 / 2000$ & $12 / 31 / 2010$ & 11 & 539 & 5 \\
\hline E1M3A & $35^{\circ} 46^{\prime} 990^{\prime \prime}$ & $24^{\circ} 54^{\prime} 880^{\prime \prime}$ & 1440 & 40.31 & $05 / 28 / 2007$ & $01 / 01 / 2011$ & 3.6 & 493 & 4 \\
\hline Kalamata & $36^{\circ} 58^{\prime} 283^{\prime \prime}$ & $22^{\circ} 05^{\prime} 620^{\prime \prime}$ & 340 & 4.13 & $12 / 31 / 1999$ & $01 / 01 / 2011$ & 11 & 206 & 2 \\
\hline Lesvos & $39^{\circ} 09^{\prime} 346^{\prime \prime}$ & $25^{\circ} 48^{\prime} 472^{\prime \prime}$ & 121 & 2.82 & $12 / 31 / 1999$ & $01 / 01 / 2011$ & 11 & 693 & 6 \\
\hline Mykonos & $37^{\circ} 30^{\prime} 690^{\prime \prime}$ & $25^{\circ} 27^{\prime} 494^{\prime \prime}$ & 138 & 4.41 & $12 / 31 / 1999$ & $01 / 01 / 2011$ & 11 & 971 & 7 \\
\hline Petrokaravo & $37^{\circ} 35^{\prime} 915^{\prime \prime}$ & $23^{\circ} 33^{\prime} 715^{\prime \prime}$ & 211 & 8.93 & $08 / 28 / 2007$ & $01 / 01 / 2011$ & 3.3 & 368 & 3 \\
\hline Pylos & $36^{\circ} 49^{\prime} 533^{\prime \prime}$ & $21^{\circ} 35^{\prime} 762^{\prime \prime}$ & 1681 & 8.17 & $11 / 09 / 2007$ & $01 / 01 / 2011$ & 3.1 & 444 & 4 \\
\hline Santorini & $36^{\circ} 15^{\prime} 510^{\prime \prime}$ & $25^{\circ} 29^{\prime} 769^{\prime \prime}$ & 314 & 9.21 & $12 / 31 / 1999$ & $01 / 01 / 2011$ & 11 & 590 & 5 \\
\hline Skyros & $39^{\circ} 06^{\prime} 360^{\prime \prime}$ & $24^{\circ} 27^{\prime} 568^{\prime \prime}$ & 117 & 13.92 & $08 / 28 / 2007$ & $01 / 01 / 2011$ & 3.3 & 540 & 5 \\
\hline Zakynthos & $37^{\circ} 56^{\prime} 927^{\prime \prime}$ & $20^{\circ} 36^{\prime} 059^{\prime \prime}$ & 313 & 6.81 & $11 / 08 / 2007$ & $01 / 01 / 2011$ & 3.1 & 469 & 4 \\
\hline
\end{tabular}

$\mathrm{DFL}=$ Distance from land. Wind classes: $2=$ Marginal, $3=$ Fair, $4=$ Good, $5=$ Excellent, $6=$ Outstanding, $7=$ Superb.

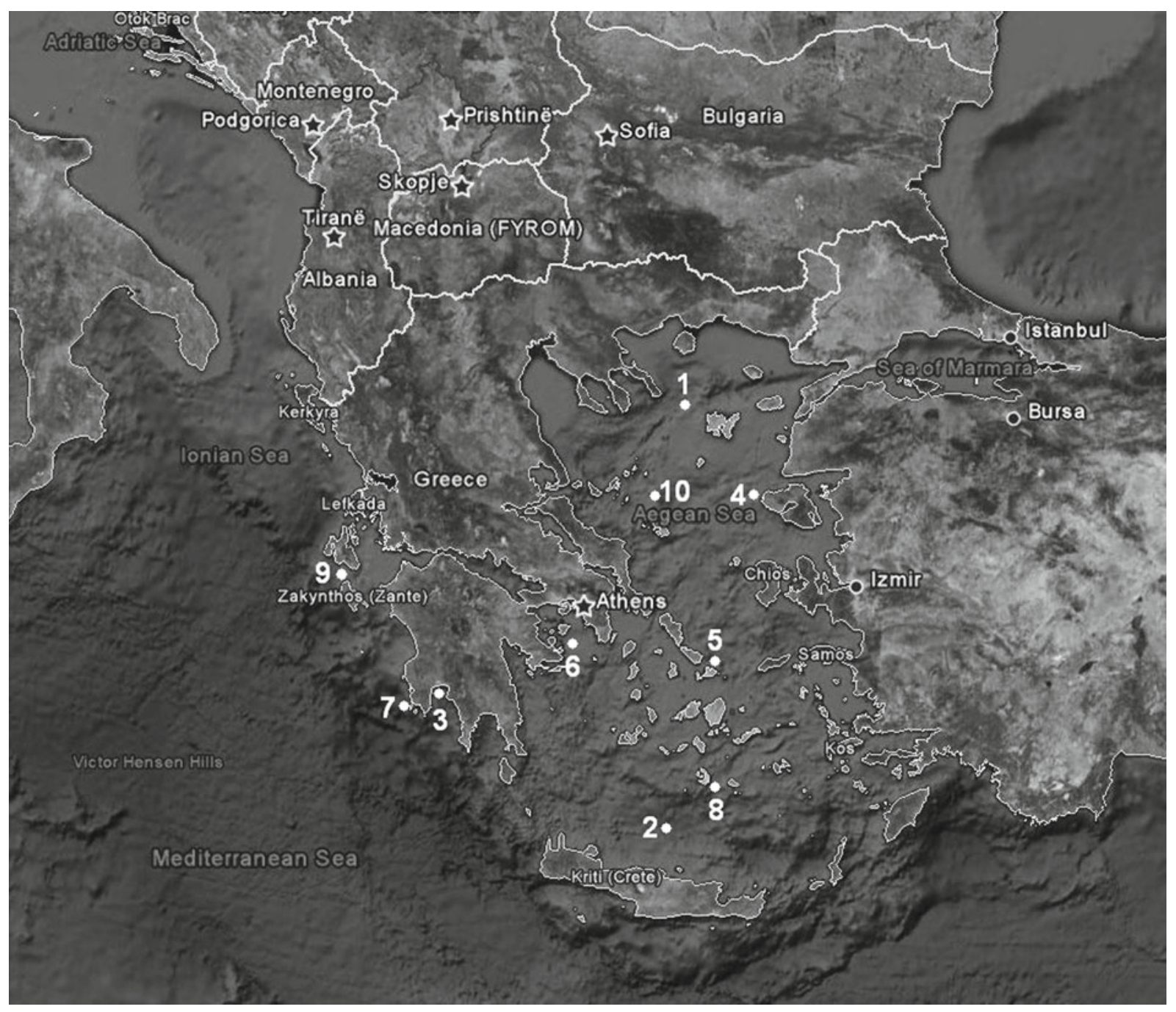

Figure 1. Map of Ionian and Aegean seas with the sites of the buoys: 1. Athos 2. E1M3A 3. Kalamata 4. Lesvos 5 . Mykonos 6. Petrokaravo 7. Pylos 8. Santorini 9. Zakynthos and 10. Skyros.

during the mild winter season, these winds alternate with southwesterlies. The Etesians are the strong, dry north winds of the Aegean Sea, which blow from about mid-May to mid-September. The barometric conditions that cause these prevailing winds are the existence of both high barometric 

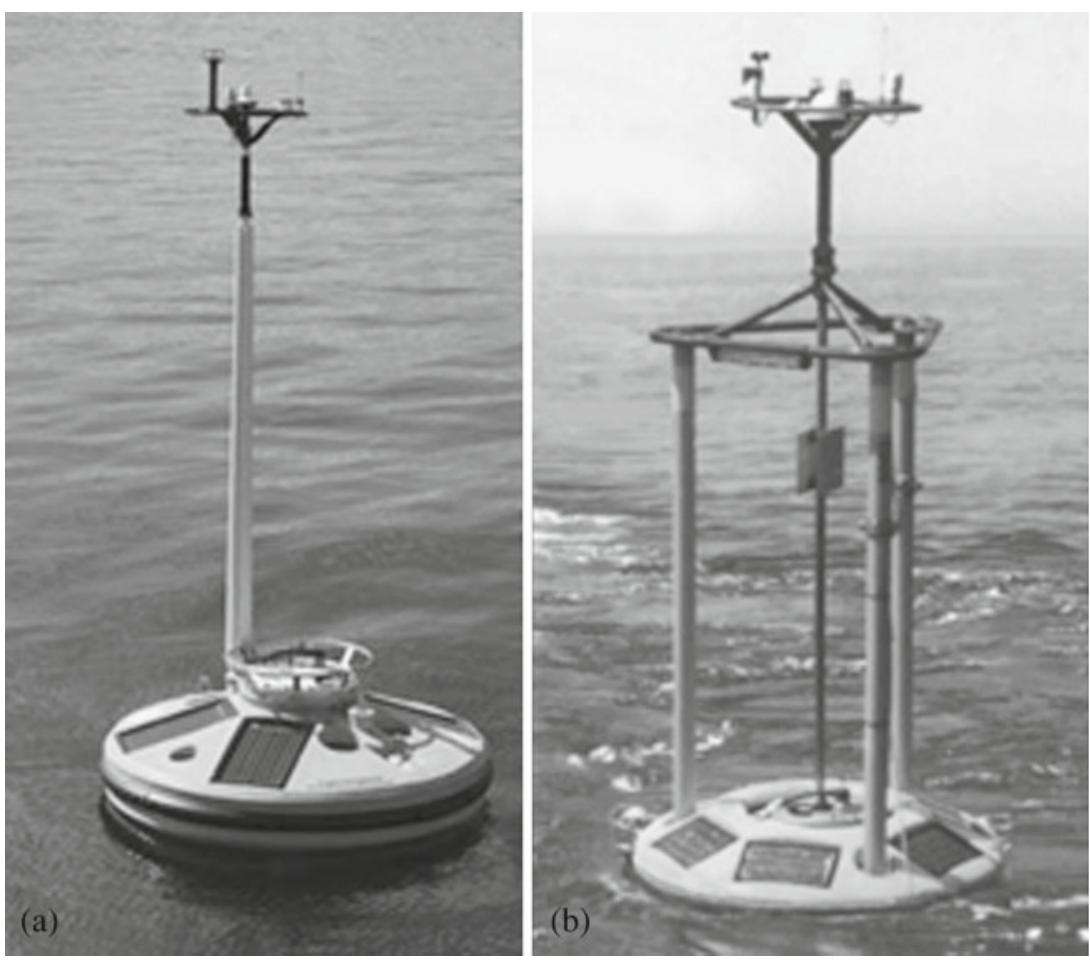

Figure 2. Views of the Oceanor Wavescan (a) and Oceanor SeaWatch (b) instrumented buoys used at these stations.

Table 2. Turbulence intensity values for the selected sites.

\begin{tabular}{lcccccc}
\hline Location & WS3 & WS10 & SD3 & SD10 & Turbulence 3 & Turbulence 10 \\
\hline Athos & 4.73 & 5.47 & 3.43 & 3.96 & 0.837 & 0.724 \\
E1M3A & 5.30 & 6.14 & 2.75 & 3.18 & 0.600 & 0.518 \\
Kalamata & 3.66 & 4.24 & 2.35 & 2.72 & 0.743 & 0.642 \\
Lesvos & 5.84 & 6.75 & 3.41 & 3.93 & 0.673 & 0.582 \\
Mykonos & 6.70 & 7.76 & 3.56 & 4.12 & 0.615 & 0.531 \\
Petrokaravo & 4.67 & 5.42 & 2.75 & 3.19 & 0.683 & 0.589 \\
Pylos & 4.97 & 5.77 & 2.88 & 3.35 & 0.674 & 0.581 \\
Santorini & 5.58 & 6.47 & 3.02 & 3.50 & 0.627 & 0.541 \\
Skyros & 53.33 & 6.18 & 3.17 & 3.67 & 0.069 & 0.594 \\
Zakynthos & 4.90 & 5.68 & 2.93 & 3.39 & 0.692 & 0.597 \\
\hline
\end{tabular}

pressures over the central Balkans and low pressures over Turkey (Akdağ et al. 2010). During hot summer days, they are at their strongest in the afternoon and often die down at night, but sometimes these winds last for days without a break. Similar winds blow in the Adriatic and Ionian regions. In the northern Aegean Sea, the Etesians blow as winds of northeasterly to northerly direction. Moving south, in the central Aegean, they blow as winds of northerly direction, while, in the southern Aegean, the Cretan and the Carpathian Sea, they blow as northwesterlies. The same winds blow in Cyprus as westerlies to southwesterlies, being more humid (Incecik and Erdogmus 1995; Poulos et al. 1997; Borhan 1998; Hamad et al. 2006; Klaić et al. 2009).
The tides of the Aegean basin seem to follow the movements of those in the eastern Mediterranean generally. Aegean currents generally are not smooth, whether considered from the viewpoint of either speed or direction. They are chiefly influenced by blowing winds. Water temperatures in the Aegean are influenced by the cold-water masses of low temperature that flow in from the Black Sea to the northeast. The sea surface temperature in the Aegean ranges from about $60^{\circ}-77^{\circ} \mathrm{F}\left(16^{\circ}-25^{\circ} \mathrm{C}\right)$, varying with location and time of year.

The turbulence intensity values for the selected sites are calculated as the quotient of the standard deviation to the average wind speed $(\sigma$ /average WS) and are given in table 2 (Belu and Koracin 2009; Yu and Gan Chowdhury 2009). For 
overwater wind speed measurements, a preliminary estimation of the gust factor $G$ (which is defined as the ratio of the maximum gust speed to the sustained wind speed) could be done via the following empirical formulation (Hsu 2001, 2003a, 2003b):

$$
G=1+2 P
$$

where $G$ is the gust factor and $P$ is the exponent of the power-law wind profile of a selected site. Consequently, the gust factor value for the selected sites, as given by the aforementioned relationship, is $G=1.246$ at all sites, as the wind shear exponent was 0.123 with roughness length of $0.0016 \mathrm{~m}$ and roughness class of 0.42 (there is a uniformity in the characteristics of water body and there is no change in surface roughness).

As preliminary assessment and magnitude of wind power density calculated at $50 \mathrm{~m}$ above ground level (AGL), Mykonos was classified as the superb windy site with class 7 winds and wind power density of $971 \mathrm{~W} / \mathrm{m}^{2}$. Petrokaravo and Kalamata, with wind power densities of 368 and $206 \mathrm{~W} / \mathrm{m}^{2}$, were classified as the fair and marginal sites with wind power class of 3 and 2, respectively as mentioned in the last column of table 1. All the other sites were found to be between good and outstanding.
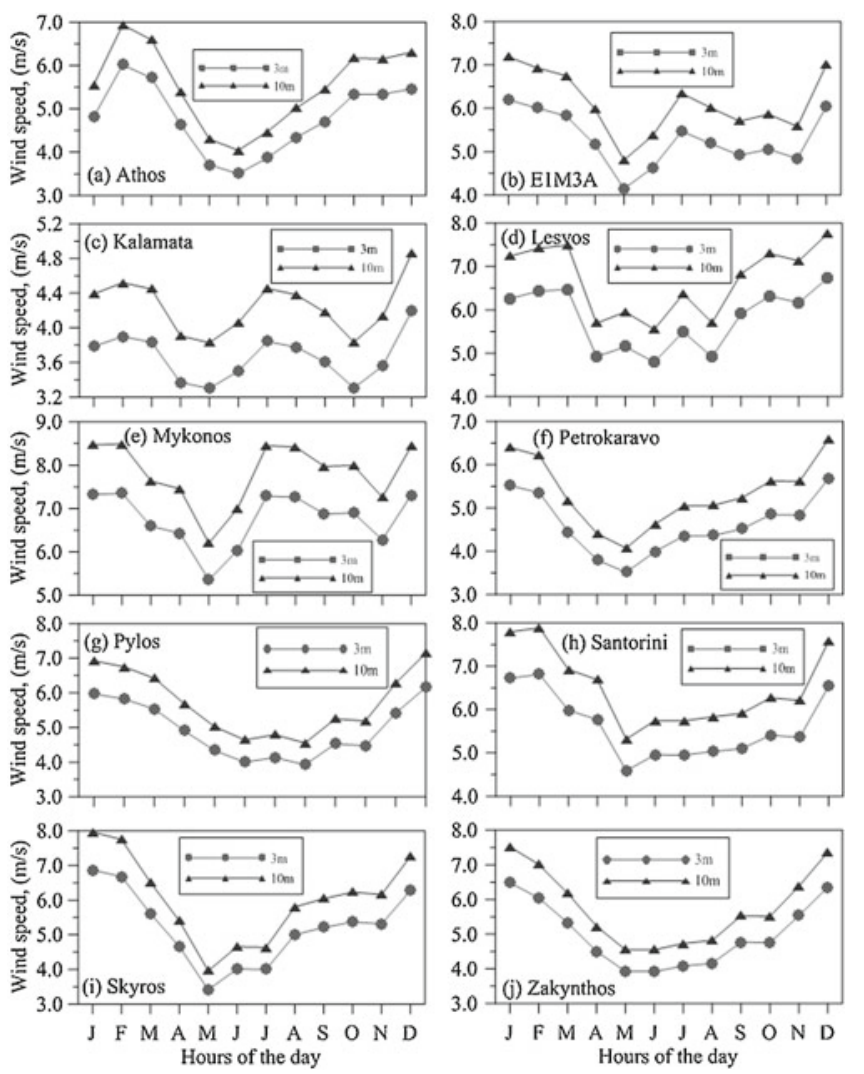

Figure 3. Monthly variation of wind speed at all the stations.

\section{Results and discussion}

The wind speed and direction data analysis was performed using the state-of-the-art software 'Windographer', made specifically for wind data analysis (Windographer). The annual, monthly and three hourly mean wind speed statistics; the Weibull parameters $k$ and $c$ using maximum likelihood, WAsP, and least square methods; the frequency distribution; and finally the wind energy yield and plant capacity factors were determined and are discussed here in the forthcoming paragraphs.

\subsection{Annual, seasonal and diurnal variation of wind speed}

The annual mean wind speed values are usually used to get a rough estimate of wind energy yield from a particular wind turbine and for a particular site. The annual mean wind speeds further help in providing the decreasing or increasing trends during the coming years, which are required to estimate the energy yield and thus the economics of the wind power development in that region or area. In the present case, the annual wind speed values were available for 11 years at only four
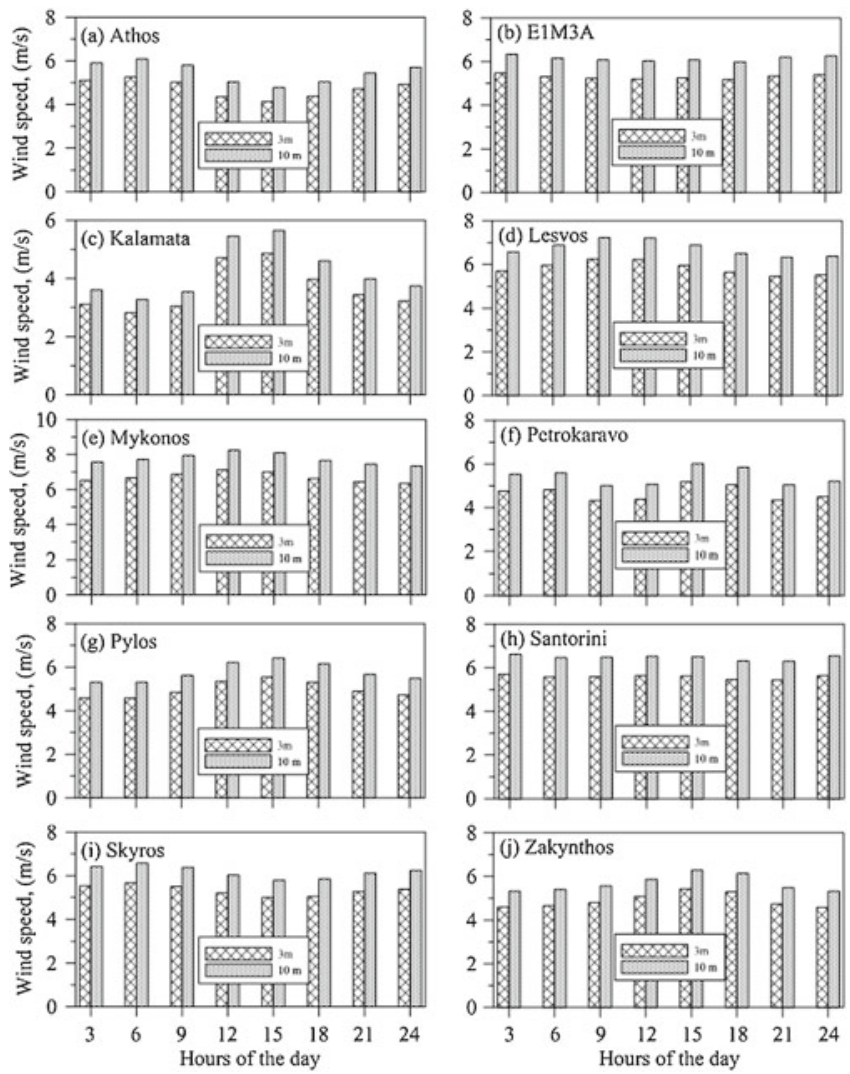

Figure 4. Diurnal variation of 3 hourly mean wind speeds at all the stations. 
locations out of the 10 used in the present work. At Athos, the annual mean wind speeds were always greater than $4.5 \mathrm{~m} / \mathrm{s}$ at 3 and $10 \mathrm{~m}$ above water surface, with the exception of year 2003. The linear best fit trends show increasing trends from years 2000 to 2010. This implies that the wind power development and utilization at Athos will be a good option for profit making, looking from the investment point of view.

In Lesvos, the annual mean wind speed was always above $5 \mathrm{~m} / \mathrm{s}$, except in the year 2005 and 2007, when it was a bit less. Overall, the linear trend showed a slightly decreasing pattern which may be due to some operational and maintenance procedures but need to be verified with more years of data from nearby historical meteorological station. The annual mean wind speed was above $6 \mathrm{~m} / \mathrm{s}$ in all years at $10 \mathrm{~m}$. At Mykonos, the annual mean wind speed was most of the times above $6.5 \mathrm{~m} / \mathrm{s}$ at measurement heights of 3 and $10 \mathrm{~m}$ above water surface level and hence is expected to be much higher at 100 to $120 \mathrm{~m}$ above the water surface level. In 2001 and 2006, annual mean wind speeds of more than $8 \mathrm{~m} / \mathrm{s}$ were noticed at this site. The

Table 3. Summary of Weibull parameters, fits and the $R^{2}$ va1ues for different methods at $10 \mathrm{~m}$.

\begin{tabular}{|c|c|c|c|c|}
\hline & Weibull & Weibull & Mean & $R^{2}$ \\
\hline Algorithm & $\mathrm{k}$ & $c(\mathrm{~m} / \mathrm{s})$ & $(\mathrm{m} / \mathrm{s})$ & \\
\hline \multicolumn{5}{|l|}{ (a) Athos } \\
\hline Maximum likelihood & 1.24 & 5.81 & 5.42 & 0.90 \\
\hline Least squares & 0.93 & 6.41 & 6.63 & 0.77 \\
\hline WAsP & 1.51 & 6.21 & 5.60 & 0.86 \\
\hline \multicolumn{5}{|l|}{ (b) E1M3A } \\
\hline Maximum likelihood & 1.99 & 6.91 & 6.12 & 0.94 \\
\hline Least squares & 1.86 & 7.02 & 6.23 & 0.93 \\
\hline WAsP & 1.73 & 6.51 & 5.80 & 0.87 \\
\hline \multicolumn{5}{|l|}{ (c) Kalamata } \\
\hline Maximum likelihood & 1.49 & 4.66 & 4.21 & 0.94 \\
\hline Least squares & 1.23 & 4.90 & 4.58 & 0.90 \\
\hline WAsP & 1.88 & 5.05 & 4.49 & 0.89 \\
\hline \multicolumn{5}{|l|}{ (d) Lesvos } \\
\hline Maximum likelihood & 1.62 & 7.45 & 6.67 & 0.79 \\
\hline Least squares & 1.14 & 8.25 & 7.88 & 0.59 \\
\hline WAsP & 2.74 & 8.52 & 7.58 & 0.69 \\
\hline \multicolumn{5}{|l|}{ (e) Mykonos } \\
\hline Maximum likelihood & 1.78 & 8.59 & 7.64 & 0.70 \\
\hline Least squares & 1.20 & 9.53 & 8.96 & 0.43 \\
\hline WAsP & 3.85 & 9.78 & 8.84 & 0.61 \\
\hline \multicolumn{5}{|l|}{ (f) Petrokaravo } \\
\hline Maximum likelihood & 1.72 & 6.06 & 5.41 & 0.92 \\
\hline Least squares & 1.63 & 6.11 & 5.47 & 0.93 \\
\hline WAsP & 2.48 & 6.77 & 6.00 & 0.73 \\
\hline \multicolumn{5}{|l|}{ (g) Pylos } \\
\hline Maximum likelihood & 1.77 & 6.48 & 5.76 & 0.95 \\
\hline Least squares & 1.71 & 6.51 & 5.80 & 0.95 \\
\hline WAsP & 1.85 & 6.57 & 5.83 & 0.94 \\
\hline \multicolumn{5}{|l|}{ (h) Santorini } \\
\hline Maximum likelihood & 1.82 & 7.21 & 6.41 & 0.93 \\
\hline Least squares & 1.32 & 7.87 & 7.24 & 0.73 \\
\hline WAsP & 2.33 & 7.71 & 6.83 & 0.93 \\
\hline \multicolumn{5}{|l|}{ (i) Skyros } \\
\hline Maximum likelihood & 1.70 & 6.91 & 6.16 & 0.94 \\
\hline Least squares & 1.57 & 7.02 & 6.31 & 0.94 \\
\hline WAsP & 2.02 & 7.33 & 6.49 & 0.88 \\
\hline \multicolumn{5}{|l|}{ (j) Zakynthos } \\
\hline Maximum likelihood & 1.71 & 6.36 & 5.67 & 0.95 \\
\hline Least squares & 1.64 & 6.40 & 5.72 & 0.96 \\
\hline WAsP & 2.05 & 6.78 & 6.01 & 0.88 \\
\hline
\end{tabular}


annual mean wind speeds showed increasing trends in the coming years. At Santorini, a visible decreasing trend of around $2.5 \%$ per year was observed in the annual mean wind speeds, but the annual mean wind speed was always greater than $6 \mathrm{~m} / \mathrm{s}$ and even above $7 \mathrm{~m} / \mathrm{s}$ in some years.
The seasonal trends at Athos showed higher wind speeds of about $5 \mathrm{~m} / \mathrm{s}$ from January to April and then decreasing towards June and again increasing towards end of the year, reaching above $6 \mathrm{~m} / \mathrm{s}$ at both measurement heights, as shown in figure 3(a). This implies that a wind turbine with
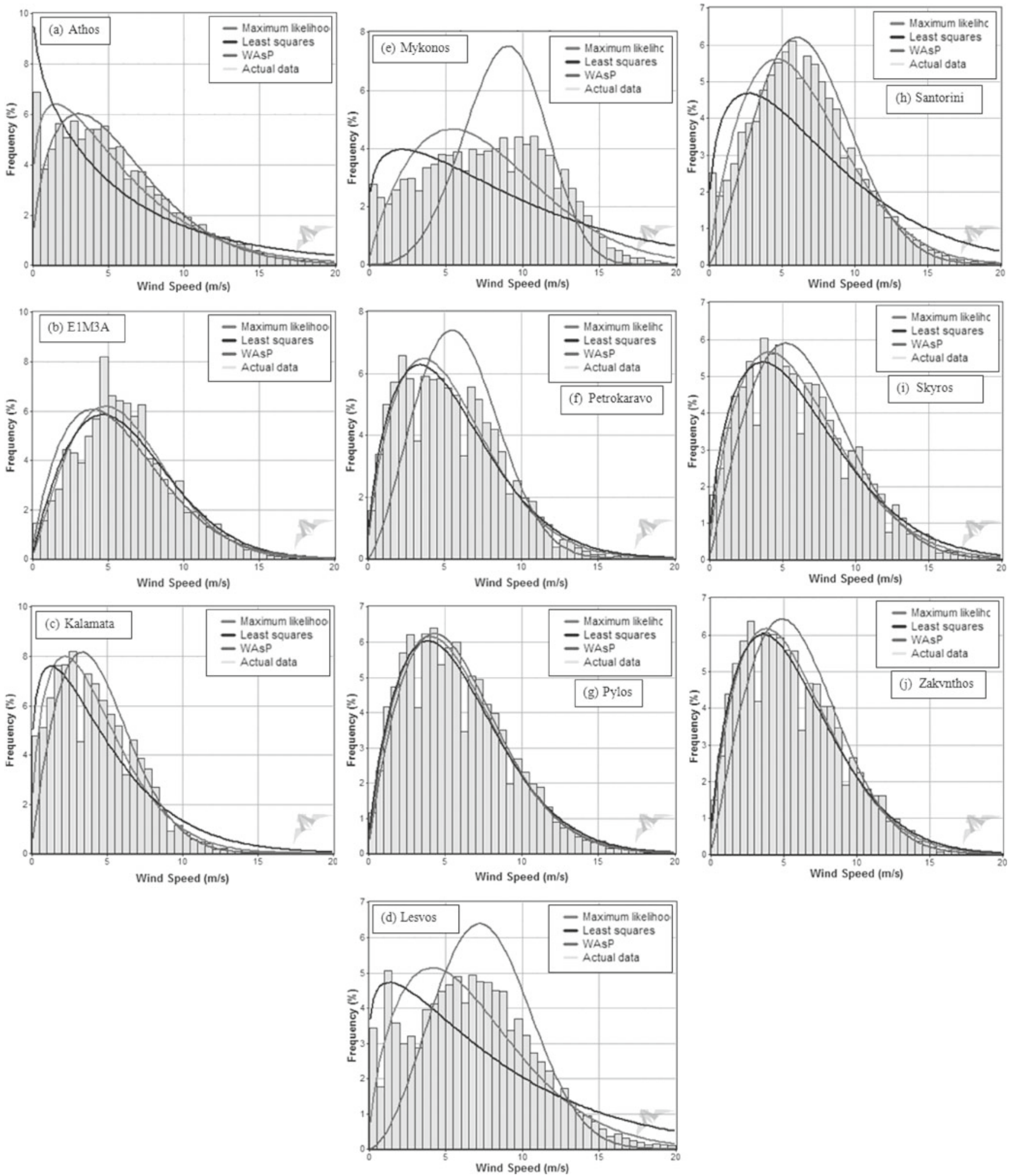

Figure 5. Frequency distribution and Weibull fits using different methods. 
cut-in-speed of $4 \mathrm{~m} / \mathrm{s}$ can produce energy during all the months except from May to July. Higher winds of more than $5 \mathrm{~m} / \mathrm{s}$ were observed during all the months except in May at E1M3A station (figure $3 \mathrm{~b}$ ). At all the measurement stations, higher winds were observed during winter time and relatively lower during summer time at both the heights. Clearly, higher winds were observed at $10 \mathrm{~m}$ compared to those at $3 \mathrm{~m}$ above water surface level.

The diurnal variation of 3-hourly mean wind speed at 3 and $10 \mathrm{~m}$ above water surface level for all the buoy stations is shown in figure 4 . At all of these stations the mean wind speeds at $10 \mathrm{~m}$ were around 15\%-16\% higher than those at $3 \mathrm{~m}$ measurement height. At Athos, Petrokaravo and Syros stations' lower values of 3-hourly mean wind speeds were observed 12 to 15 hours and higher at other hours of the day. At all the remaining stations the mean wind speeds were higher from 12 to 18 hours in general and lower during remaining hours of the day as can be seen from figure 4 .

\subsection{Weibull and frequency distribution analysis}

The speed of the wind is well represented by Weibull distribution function and it is widely used for wind power estimation and resource assessment. In the present scope of the work, Weibull parameters $k$ and $c$ were determined using Maximum likelihood, least squares and WAsP methods and for entire dataset at both 3 and $10 \mathrm{~m}$ measurement heights. For the sake of space optimization, the $k$ and $c$ values are presented for measurements made at $10 \mathrm{~m}$. In most of the cases, WAsP method provides highest values of shape parameter $k$ and scale parameter $c$, as can be observed from table 3 . The Weibull parameters were used to find the best fit curves and compared with the measured wind speed in different wind speed bins are shown in figure $5(\mathrm{a}-\mathrm{j})$. At Athos, the most close agreement between the Weibull distribution function and the measured wind speed was obtained by maximum likelihood method with $R^{2}=0.90$, while the least close agreement by least square method with $R^{2}=0.77$. The comparison is shown in figure 5(a). Almost at all the stations, maximum likelihood method gave the best comparable values of $k$ and $c$, while least square method proved the next best and WAsP at number three.

At Athos, the wind speed was above cut-in-speed of $4 \mathrm{~m} / \mathrm{s}$ for $52.4 \%$ of the times during the data collection period and the predominantly blown from NS (>45\%). At E1M3A, the remained above cutin-speed was appeared for more than $71 \%$ of the times and came from WN directions for $50 \%$ of the times. At Kalamata, Mykonos, and Petrokaravo, the wind remained above cut-in-speed for more than $48 \%, 67 \%$, and $60 \%$ of the times and was

Table 4. Effect of hub height on wind energy yield and plant capacity factor.

\begin{tabular}{|c|c|c|c|c|}
\hline \multicolumn{5}{|l|}{ Athos } \\
\hline Hub height (HH) & $120 \mathrm{~m}$ & $110 \mathrm{~m}$ & $100 \mathrm{~m}$ & $90 \mathrm{~m}$ \\
\hline WS at $\mathrm{HH}(\mathrm{m} / \mathrm{s})$ & 7.44 & 7.37 & 7.28 & 7.19 \\
\hline Zero output (\%) & 26.59 & 26.9 & 27.09 & 27.53 \\
\hline Rated output (\%) & 15.61 & 15.31 & 14.63 & 14.39 \\
\hline Mean power $(\mathrm{kW})$ & 1412.60 & 1391.70 & 1368.80 & 1343.60 \\
\hline Annual energy (MWh) & $12,374.5$ & $12,190.9$ & $11,990.7$ & $11,769.5$ \\
\hline $\mathrm{PCF}(\%)$ & 28.3 & 27.8 & 27.4 & 26.9 \\
\hline \multicolumn{5}{|l|}{ Mykonos } \\
\hline Hub height (HH) & $120 \mathrm{~m}$ & $110 \mathrm{~m}$ & $100 \mathrm{~m}$ & $90 \mathrm{~m}$ \\
\hline WS at $\mathrm{HH}(\mathrm{m} / \mathrm{s})$ & 10.54 & 10.43 & 10.31 & 10.18 \\
\hline Zero output (\%) & 12.86 & 12.98 & 13.08 & 13.19 \\
\hline Rated output (\%) & 35.98 & 354 & 33.96 & 33.36 \\
\hline Mean power $(\mathrm{kW})$ & 2411.0 & 2388.4 & 2363.5 & 2335.1 \\
\hline Annual energy (MWh) & $21,120.0$ & $20,922.5$ & $20,703.9$ & $20,455.9$ \\
\hline $\mathrm{PCF}(\%)$ & 48.2 & 47.8 & 47.3 & 46.7 \\
\hline \multicolumn{5}{|l|}{ Santorini } \\
\hline Hub height (HH) & $120 \mathrm{~m}$ & $110 \mathrm{~m}$ & $100 \mathrm{~m}$ & $90 \mathrm{~m}$ \\
\hline WS at $\mathrm{HH}(\mathrm{m} / \mathrm{s})$ & 8.79 & 8.7 & 8.6 & 8.48 \\
\hline Zero output (\%) & 13.52 & 13.68 & 13.81 & 14 \\
\hline Rated output (\%) & 18.14 & 17.63 & 16.7 & 16.15 \\
\hline Mean power $(\mathrm{kW})$ & 1856.4 & 1827.2 & 1795.2 & 1759.6 \\
\hline Annual energy (MWh) & $16,262.3$ & $16,006.3$ & $15,726.0$ & $15,414.1$ \\
\hline $\mathrm{PCF}(\%)$ & 37.1 & 36.5 & 35.9 & 35.2 \\
\hline
\end{tabular}


found to be blowing predominantly from NE, NNS-NE, and NW, respectively. At remaining stations, the wind speed remained above cut-in-speed for more than $62 \%$ of the times. The wind direction was mostly found to be from $\mathrm{N}$.

\subsection{Wind energy yield estimation and effect of hub height}

The energy yield was obtained using an offshore wind turbine of $5 \mathrm{MW}$ rated power from REPower, with electrical blade angle adjustment - pitch and speed control (Windographer). The technical specifications of the chosen wind turbine were rotor diameter $=126 \mathrm{~m}$, cut-in-speed $=4 \mathrm{~m} / \mathrm{s}$, rated speed $=13 \mathrm{~m} / \mathrm{s}$, cut-out-speed $=30 \mathrm{~m} / \mathrm{s}$, and different hub heights $(\mathrm{HH})$ ranging from 90 to $120 \mathrm{~m}$ with an increment of $10 \mathrm{~m}$. The overall losses were taken as $17.7 \%$ which include down time losses of $6 \%$, array losses of $5 \%$, icing/soiling losses of another $4 \%$, and finally the other unaccountable losses of $4 \%$. Of the 10 buoy stations, the energy yield was estimated for all the stations, but details are given only for Athos, Mykonos and Santorini stations in table 4.

At Athos, the chosen turbine could produce $12,375 \mathrm{MWh}$ of electricity annually with a plant capacity factor (PCF) of $28.3 \%$ and with zero output of $26.6 \%$ and rated output of $15.61 \%$ of the times during the year with $120 \mathrm{~m}$ hub height $(\mathrm{HH})$, as summarized in table 4. At $120 \mathrm{~m} \mathrm{HH}$ the wind



Figure 6. Annual mean wind energy yield at $\mathrm{HH}=90 \mathrm{~m}$.

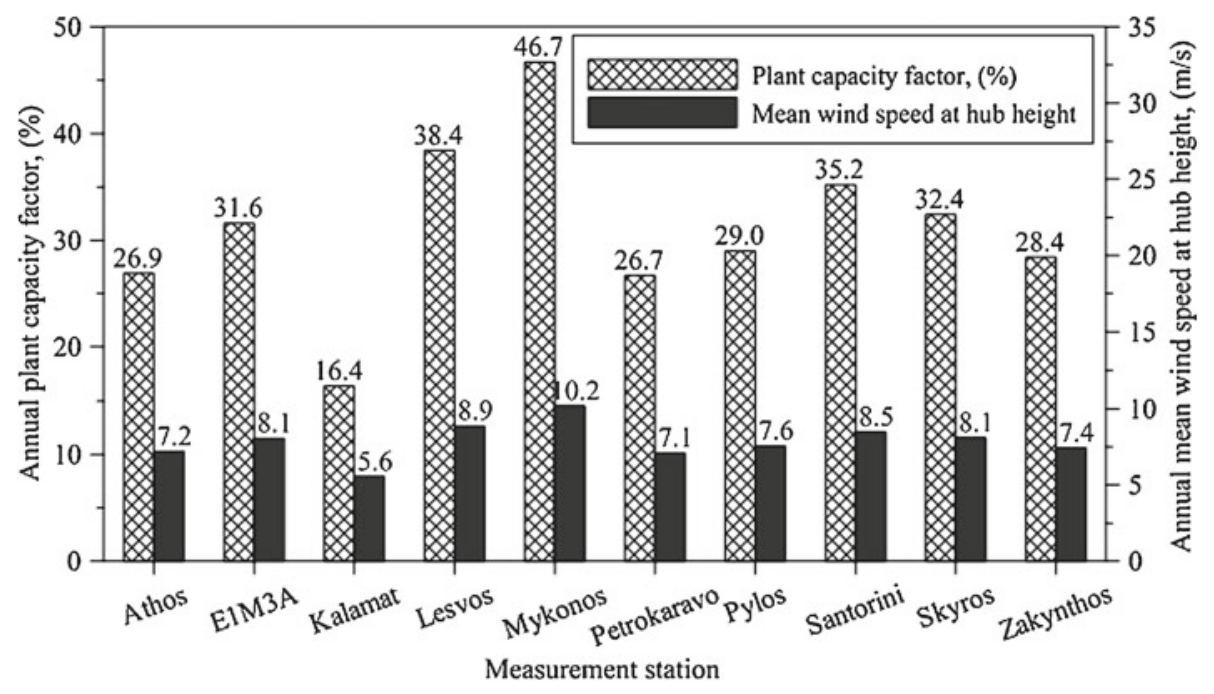

Figure 7. Annual mean wind speed and PCF at $\mathrm{HH}=90$. 


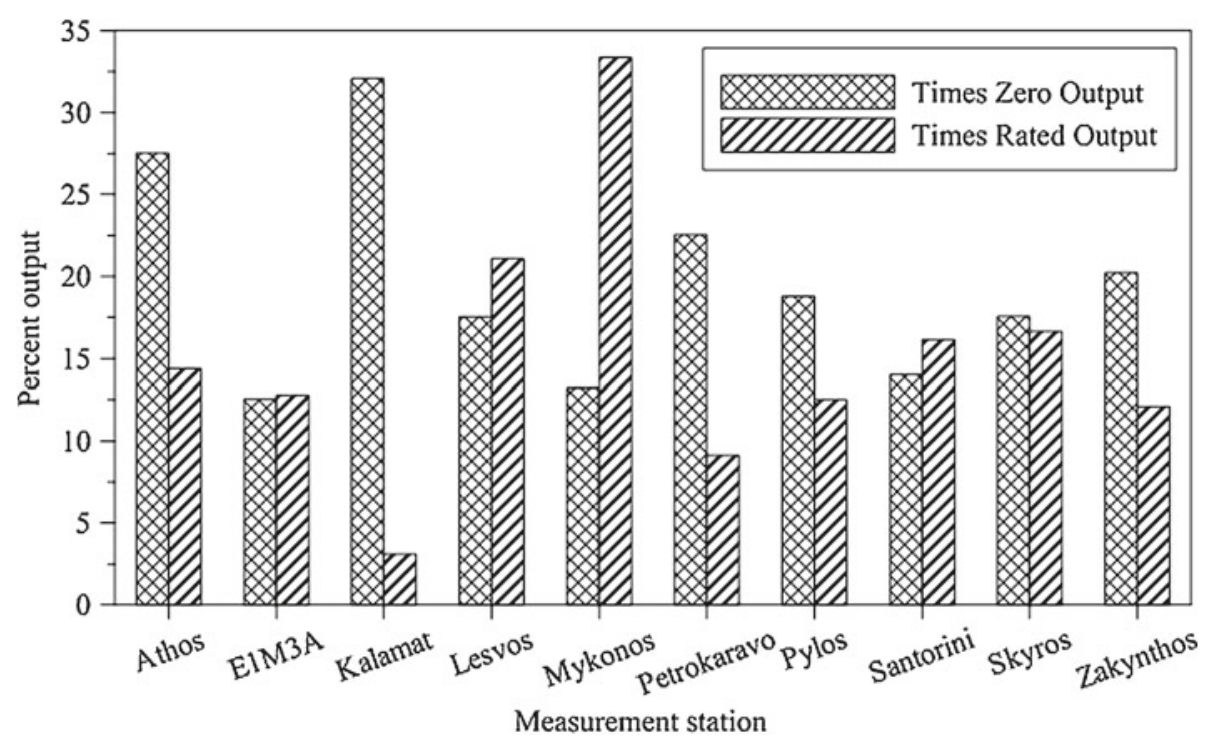

Figure 8. Percent rated and zero energy output.

speed was $7.44 \mathrm{~m} / \mathrm{s}$. Slight increases of 1.9\%, 1.7\%, and $1.5 \%$ were found in energy yield while increasing the $\mathrm{HH}$ from 90 to $100 \mathrm{~m}, 100$ to $110 \mathrm{~m}$ and from 110 to $120 \mathrm{~m}$ while the corresponding changes in PCF were 0.5, 0.4, and 0.5. At Mykonos station, which is the best location from energy harnessing point of view, the increases in energy yield were $0.2 \%, 1.1 \%$, and $0.9 \%$ with changes in $\mathrm{HH}$ heights from 90 to $100 \mathrm{~m}, 100$ to $110 \mathrm{~m}$ and 110 to $120 \mathrm{~m}$, respectively. However, the PCF's were $46.7 \%, 47.3 \%, 47.8 \%$ and $48.2 \%$ corresponding to HH's of 90, 100, 110, and $120 \mathrm{~m}$, as listed in table 4. At Mykonos, as given in the aforementioned table, the rated output was obtained for more than $35 \%$ of the times and the zero output was about $13 \%$ of the times during the year. The annual mean wind speeds at respective HH's were always greater than $10 \mathrm{~m} / \mathrm{s}$. At Santorini station the annual mean wind speeds at HH's of 90 to $120 \mathrm{~m}$ were found to be varying from 8.48 to $8.79 \mathrm{~m} / \mathrm{s}$, as can be seen from table 4 . The chosen wind turbine was able to produce 15,414, 15,726, 16,006 and 16,262 MWh of electricity annually corresponding to different HH's. The corresponding PCF's were found to be $35.2 \%, 35.9 \%, 36.5 \%$, and $37.1 \%$, respectively. The rated output at this site was achieved more than $16 \%$ of the times during the year, while the zero output was observed to be around $13.5 \%$ of the times, as summarized in table 4.

The annual energy output at all the sites is compared in figure 6 and PCF's in figure 7, for the designed $\mathrm{HH}$ of $90 \mathrm{~m}$. Maximum energy of 20.46 GWh was obtained at Mykonos station and the minimum of $7.17 \mathrm{GWh}$ at Kalamata, as shown in figure 6 . The second and third best sites with higher energy yields of 16.82 and 15.51 GWh were
Lesvos and Santorini, respectively. Similarly, the corresponding higher PCF's of $46.7 \%, 38.4 \%$, and $35.2 \%$ were obtained at Mykonos, Lesvos, and Santorini. The annual wind speeds at $90 \mathrm{~m} \mathrm{HH}$ are also depicted in this figure. On the other hand, the percent maximum and minimum zero and rated energy output was observed at Kalamata at $90 \mathrm{~m}$ $\mathrm{HH}$, as can be seen from figure 8 . The maximum rated output was observed at Mykonos at this $\mathrm{HH}$.

\section{Conclusions}

The study found that most of the stations could be used for the development of technically feasible wind farms, but consideration of the depth of the sea and the distance from the land to the sites needed to complete the benefit of the study. Specifically following main findings could be of use to readers and wind power seekers in Ionian and Aegean seas:

- Maximum mean wind speed of $7.8 \mathrm{~m} / \mathrm{s}$ was found at Mykonos and the minimum of $4.2 \mathrm{~m} / \mathrm{s}$ at Kalamata. At all stations the overall mean wind speed was more than $5 \mathrm{~m} / \mathrm{s}$.

- The seasonal trends were quite visible with higher values in winter time and lower in summer season with minimum in May and June.

- The diurnal pattern of 3-hourly mean wind speed showed, usually, higher valued during 12 to 21 hours and relatively during rest of the hours of the day.

- The wind was found to be flowing predominantly from N, NE, NW, W, WN, E, and EN directions.

- Based on the availability of wind speed data of around 11 years, the annual wind speed trends 
were studied for Athos, Lesvos, Mykonos and Santorini. Slightly decreasing trends were found at Lesvos and Santorini but increasing at Athos and Mykonos.

- The wind speed distribution was found to be well represented by Weibull parameters obtained using Maximum likelihood method compared to WAsP and Method of Moments.

- At all stations the chosen wind turbine could produce energy for more than $70 \%$ of the time. The wind speed distribution was found to be well represented by Weibull parameters obtained using Maximum likelihood method compared to WAsP and Method of Moments.

- Maximum energy of 20.46 GWh was obtained at Mykonos station and the minimum of $7.17 \mathrm{GWh}$ at Kalamata. The second and third best sites with higher energy yields of 16.82 and 15.51 GWh were Lesvos and Santorini, respectively.

- Similarly, the higher PCF's of 46.7\%, 38.4\%, and $35.2 \%$ were obtained at Mykonos, Lesvos, and Santorini.

- The effect of HH was very minimal. At all the sites studied, the wind energy was found to increase only by less than 1 to little more than $1 \%$ for each increment of $10 \mathrm{~m}$. This necessitates the measurements of wind speed at least at three sites, viz, Mykonos, Lesvos and Santorini at different heights and up to $120 \mathrm{~m}$ above the water surface. These measurements will provide more accurate local wind shear exponents and hence the exact wind speed at hub height.

\section{Acknowledgements}

The authors wish to acknowledge the support of the Research Institute of King Fahd University of Petroleum and Minerals, Dhahran, Saudi Arabia and the Hellenic Centre for Marine Research Poseidon Team for the access to the Centre's buoys database.

\section{References}

Akdağ S A, Bagiorgas H S and Mihalakakou G 2010 Use of two-component Weibull mixtures in the analysis of wind speed in the Eastern Mediterranean; Appl. Energ. 87 2566-2573.

Bailey B, Brennan S, Kinal B, Markus M and Kreiselman J 2002 Long islands offshore wind energy development potential: Phase 1. Preliminary, Assessment; AWS Scientific Inc.

Belu R and Koracin D 2009 Wind characteristics and wind energy potential in western Nevada; Renew. Energ. 34 2246-2251.

Bilgili M, Yasar A and Simsek E 2011 Offshore wind power development in Europe and its comparison with onshore counterpart; Renew. Sust. Energ. Rev. 15 905-915.
Borhan Y 1998 Mesoscale interactions on wind energy potential in the northern Aegean region: A case study; Renew. Sust. Energ. Rev. 2(4) 353-360.

Dhanju A, Whitaker P and Kempton W 2008 Assessing offshore wind resources: An accessible methodology; Renew. Energ. 33 55-64.

Dvorak M J, Archer C L and Jacobson M Z 2010 California offshore wind energy potential; Renew. Energ. 35 12441254.

Esteban M D, Diez J J, López J S and Negro V 2011 Why offshore wind energy?; Renew. Energ. 36 444-450.

EWEA 2010 statistics: Offshore and eastern Europe new growth drivers for wind power in Europe http://www.ewea.org/index.php?id=60\&no_cache=1\&tx ttnews[tt_news] $=1896 \&$ tx_ttnews[backPid] $=1 \& \mathrm{cHash}=$ 8b64626e4bf6996eea71ec3c08994b0a (accessed on February 2, 2011).

Gaudiosi G 1994 Offshore wind energy in the Mediterranean and other European seas; Renew. Energ. 5(1) 675-691.

Hamad N, Millot C and Taupier-Letage I 2006 The surface circulation in the eastern basin of the Mediterranean Sea; Sci. Mar. 70(3) 457-503.

Hsu S A 2001 Spatial variations in gust factor across the coastal zone during Hurricane Opal in 1995; Natl. Wea. Dig. 25(1-2) 21-23.

Hsu S A 2003a Estimating overwater friction velocity and exponent of power-law wind profile from gust factor during storms; J. Waterw. Port C.-ASCE 129(4) 174177.

Hsu S A 2003b A gust-factor criterion for rapid determination of atmospheric stability and mixing height for overwater dispersion estimates; Natl. Wea. Dig. 27 70-74.

Incecik S and Erdogmus F 1995 An investigation of the wind power potential on the western coast of Anatolia; Renew. Energ. 6(7) 863-865.

Karamanis D, Tsabaris C, Stamoulis K and Georgopoulos D 2011 Wind energy resources in the Ionian Sea; Renew. Energ. 36 815-822.

Klaić Z B, Pasarić Z and Tudor M 2009 On the interplay between sea-land breezes and Etesian winds over the Adriatic; J. Marine Syst. 78(1) S101-S118.

Manwell J F, Rogers A L, McGowan J G and Bailey B H 2002 An offshore wind resource assessment study for New England; Renew. Energ. 27 175-187.

Manwell J F, Elkinton C N, Rogers A L and McGowan J G 2007 Review of design conditions applicable to offshore wind energy systems in the United States; Renew. Sust. Energ. Rev. 11 210-234.

Martin Mederos A C, Medina Padron J F and Feijoo Lorenzo A E 2011 An offshore wind atlas for the Canary Islands; Renew. Sust. Energ. Rev. 15 612-620.

Musial W and Butterfield S 2004 Future for offshore wind energy in the United States; NREL/CP-500-36313, Energy Ocean 2004, Palm Beach, Florida, June 28-29.

Musial W and Ram B 2010 Large-scale offshore wind power in the United States - assessment of opportunities and barriers; September 2010 NREL/TP-500-40745.

Pimenta F, Kempton W and Garvine R 2008 Combining meteorological stations and satellite data to evaluate the offshore wind power resource of southeastern Brazil; Renew. Energ. 33 2375-2387.

Poulos S E, Drakopoulos P G and Collins M B 1997 Seasonal variability in sea surface oceanographic conditions in the Aegean Sea (Eastern Mediterranean): An overview; J. Marine Syst. 13(1-4) 225-244.

Rogers A L, Manwell J F and McGowan J G 2003 A year 2000 summary of offshore wind development in the United States; Energ. Convers. Manage. 44 215-229. 
Still D 2001 Offshore wind at Blyth; Renew. Energ. 24 545-551.

Stoutenburg E D, Jenkins N and Jacobson M Z 2010 Power output variations of co-located offshore wind turbines and wave energy converters in California; Renew. Energ. 35 2781-2791.

Windographer Version 2.21, http://www.windographer. $\mathrm{com} /$.
Yu B and Gan Chowdhury A 2009 Gust factors and turbulence intensities for the tropical cyclone environment; $J$. Appl. Meteorol. Clim. 48 534-552.

Zhixin W, Chuanwen J, Qian A and Chengmin W 2009 The key technology of offshore wind farm and its new development in China; Renew. Sust. Energ. Rev. 13 $216-222$.

MS received 26 September 2011; revised 6 January 2012; accepted 12 March 2012 